\title{
Identifying magmatic overprint in orogenic gold systems: An example from Wawa, Ontario, Canada
}

\author{
E. A. WeHrLE ${ }^{1 *}$, I. M. SAMSON ${ }^{1}$, J.-F. MONTREUIL ${ }^{2}, \&$ \\ D. J. KONTAK ${ }^{3}$ \\ ${ }^{1}$ School of the Environment, University of Windsor, Windsor, \\ ON, Canada (*correspondence: wehrlee@uwindsor.ca) \\ ${ }^{2}$ Red Pine Exploration, Toronto, ON, Canada \\ ${ }^{3}$ Harquail School of Earth Sciences, Laurentian University, \\ Sudbury, ON, Canada
}

The Wawa Gold Corridor (WGC), located in the Michipicoten greenstone belt of the Superior Province, Canada, comprises gold-bearing shear zones that resulted from deformation $\left(\mathrm{D}_{1}-\mathrm{D}_{3}\right)$ of $2.75 \mathrm{Ga}$ intermediate igneous rocks. The deposit was intruded by $1.0 \mathrm{Ga}$ lamprophyre dikes that imparted a distinct riebeckite-carbonate alteration assemblage. Gold mineralization can be divided into two principal events: syn-kinematic (Au-I); and post-kinematic (Au-II). Au-I is associated with arsenopyrite and pyrite in $\mathrm{D}_{1-}$ $\mathrm{D}_{2}$ structures and occurs within or on the margins of these minerals. Au-II is hosted by carbonate ( \pm riebeckite) veinlets that cross-cut $\mathrm{D}_{3}$ veins and occurs with chalcopyrite, pyrite, and a variety of Bi-Te minerals. Au-II and Bi-Te minerals share curvilinear boundaries and often occur as trails of globular grains in quartz. Analysis of sulfide chemistry by LA-ICP-MS reveals that: (1) syn-kinematic arsenopyrite is Au rich $\left(10^{2}-10^{3} \mathrm{ppm}\right)$; (2) syn-kinematic pyrite is As rich $\left(10^{2}-10^{4} \mathrm{ppm}\right)$ and Au rich $\left(10^{0}-10^{1} \mathrm{ppm}\right)$; and (3) postkinematic pyrite is As poor $\left(10^{0}-10^{2} \mathrm{ppm}\right)$ and Au poor $(<1$ $\mathrm{ppm})$. The salient features of the Au-I event are typical of orogenic mineralization (i.e., invisible gold in Fe-As sulfides, native gold bordering these phases, and a $\mathrm{Au}$-As association), whereas the salient features of the Au-II event are atypical of orogenic mineralization (i.e., gold with $\mathrm{Bi}-\mathrm{Te}$ minerals and chalcopyrite and a Au-Bi-Te-Cu association). In fact, the mineral assemblages and textural nature of the latter indicate precipitation from Bi-rich polymetallic melts. Based on mineralogical similarities (e.g., gold in carbonate-riebeckite veinlets), these fluids were probably related to the lamprophyre dikes and re-distributed gold on a deposit scale; the WGC can therefore be described as an orogenic deposit that experienced magmatic-hydrothermal overprint. The AuII event is similar to gold mineralization in magmatic systems (e.g., skarn, IOCG) in terms of mineralizing process, mineralogy, and geochemistry. Identification of such features in other orogenic deposits may serve as evidence for a magmatic contribution. 